\title{
POST-PARTUM OVARIAN ACTIVITY IN CONCEIVED AND NON-CONCEIVED FRIESIAN COWS DURING SUMMER SEASON IN EGYPT
}

\author{
S.A. Swiefy ${ }^{1}$, S.A. Ibrahim ${ }^{2}$,A.M. Saead ${ }^{1}$ and S.M. Salem ${ }^{2}$ \\ 1-Animal Biotechnology Department Animal Production Research Institute, \\ 2- Animal Production Department, Faculty of Agriculture, Cairo University
}

\section{SUMMARY}

A total of thirty lactating Friesian cows were used to descript the post-partum ovarian activity during the first 120 days post-partum to identify the physiological reasons of conception failure of cows those were being calved during the hot season (May to August). Ovarian activity was monitored by weekly rectal palpation, and progesterone $\left(P_{4}\right)$ concentration which was monitored in blood serum twice weekly. The interval from parturition to first ovulation (PPOI) as well as ovarian cycle length, ovarian activity parameters (number of total ovulation, ovulatory estrus, quiet ovulation and non-ovulatory estrus cases/cow) and ovarian functional disorder (long anestrous period, percentage of quiet ovulation, non-ovulatory estrus, cystic follicles, persistent $C L$ and cessation of the ovulation) were determined.

Sustained anestrous cases were observed in $10 \%$ of animals during the experimental period. Remaining cows were divided into two classes, conceived $\left(G_{l}\right.$, $51.9 \%)$ and non-conceived cows $\left(G_{2 .} 48.1 \%\right)$. The length of the anestrous periods in $G_{2}$ was $(p<0.05)$ longer than in $G_{1} . G_{1}$ had $(P<0.05)$ higher frequency distribution percentage of transient $P_{4}$ rise before the first ovulation post partum than that in $G_{2}$. Progesterone profile characteristics during ovarian cycle prior the conception were $(P<0.05)$ higher in $G_{1}$ than those in the ovarian cycles during the post partum period in $G_{2}$. The length of the anestrous periods in $G_{2}$ was $(p<0.05)$ longer than in $G_{1} G_{1}$ had the lowest percentages of quiet ovulation, cystic follicles and false estrus than $G_{2}$ while the persistent $C L$ and cessation of the ovulation cases were observed only in $G_{2}$

Keywords: Cattle, post-partum, ovarian activity, progesterone

\section{INTRODUCTION}

To achieve a regular calving interval (every 12-13 months) conception has to be occurred achieved as early as they display their first ovulation. Majority of dairy cattle resume their ovarian activity within 30 days post-partum (Shipka, 2000). However, $11-46 \%$ of cows showed ovarian dysfunction during the post-partum period (Zduczyk et al., 1992; Stagnaro et al., 1994; Opsomer et al., 1998 and Rekwot et al., 2000).

Persistency of corpus luteum (2-20\%,Stagnaro et al., 1994 and Opsomer et al.,1998) , long post-partum anestrous period (20-44\%, Dawuda et al., 1989; Byongkyu et al., 1994 and Opsomer et al., 1998). and sustained anestrous ( 3-5\% of cows; Stagnaro et al. 1994; Swiefy 1997 and Opsomer et al., 1998), are common forms of ovarian disorders in cattle.

Issued by The Egyptian Society of Animal Production 
The first post-partum ovulation is usually accompanied by feeble signs of estrus (Kamimura et al., 1994). Silent ovulation occurred in range of $11 \%$ to $62 \%$ throughout the 70 to 120 days post-partum (Dawuda, et al., 1989; Shipka, 2000). Moreover, Schopper et al. (1989) and Stagnaro et al. (1994) reported that false estrus case were $6.1 \%$ and $14 \%$ respectively.

Short ovarian cycles occurs in 6-72\% during post partum period (Keeling et al., 1992; Stagnaro et al., 1994; Ghash et al., 1996 and Rekwot et al., 2000).

This study was planned to describe types of ovarian activity during the first 120 days post-partum in conceived and non-conceived Friesian cows which calved during summer season under Egyptian conditions.

\section{MATERIALS AND METHODS}

\section{Animals and Management:}

Thirty purebred multiparous Friesian cows (between $2^{\text {nd }}$ and $5^{\text {th }}$ parities) belonging to Sakha Animal Production Research Station, Agriculture Research Center, Ministry of Agriculture, Egypt (located in north eastern part of Nile Delta, Kafr El-Sheikh Governorate) were used in this study. Animals were calved throughout the period from May to August. After calving, cows were allowed to nurse their calves for four days before being machine milked; twice daily at 7.00 and $16.00 \mathrm{hr}$. Animals were housed loosely in semi-shaded open yards throughout the experimental period (till day120 post-partum).

According to live body weight and milk production level, the nutrition requirements were determined for the experimental cows. Cows were fed on concentrate mixture and rice straw until the end of the experimental period. Clean drinking water was made available all the day time for drinking.

Cows were checked for heat twice daily at 8.00 and 17:00 hr. using a vasectomized teaser. The teaser was allowed to run with the cows for 30 minutes at each check round. Standing behaviour was considered to be the main sign of heat. The reproductive tract was palpated once weekly to determine the time of uterine involution. Cows that displayed estrus at 45 days post-partum were artificially inseminated. Pregnancy was diagnosed by rectal palpation 60 days after insemination.

\section{Blood Samples:}

Blood samples were collected via the jugular vein twice weekly ( 3 to 4 days interval) to determine concentration of progesterone for monitoring ovarian activity. Samples were collected starting the first week post-partum till the end of the experiment. Samples $(5 \mathrm{ml})$ were centrifuged at $3000 \mathrm{rpm}$ for $15 \mathrm{~min}$. for serum separation. Serum samples were stored at $-20^{\circ} \mathrm{C}$ till the assay time. Direct radioimmunoassay technique (RIA) was performed using ready antibody coated tube kits (Specto Orion Diagnostics, Espoo, Finland). According to the manufacturer's information, the cross reaction of progesterone antibody (at approximately $40-60 \%$ displacement) was $100 \%$ with progesterone, while it was less than $1 \%$ other steroids, The standard curve ranged between 0.0 and $31.0 \mathrm{ng} / \mathrm{ml}$, and the sensitivity value of method was approximately $0.06-0.09 \mathrm{ng} / \mathrm{ml}$. The intra and inter assay coefficients of variation were $7.9 \%$ and $8.1 \%$ respectively. 


\section{Experimental groups:}

Cows were divided into two groups according to results of conception during the experimental period (120 days post-partum).The first group included the cows which conceived (G1) and the second one included the non conceived cows (G2). Groups were assigned to be similar in age (52-94 months), body weight (average 505.2 \pm 10.3 $\mathrm{kg}$ ), parity (2-5) and preceding lactation (average $2980 \pm 107 \mathrm{~kg}$ ).

\section{Reproductive Parameters:}

The intervals from parturition to first ovulation (PPOI), first detected estrus (PPEI) and number of ovulation per cow during the experimental period were recorded. According to the individual concentration of progesterone in serum, the complete ovarian cycles were divided according to their length into short ( $<18$ days), normal (18 - 24 days) and long cycle ( $\geq 25$ days). Quiet ovulation (ovulation without any signs of estrus) was also determined. In quiet cases day of ovulation was estimated by serum progesterone concentrations. Ovulation was considered to have occurred when progesterone level was sustained at the level of $\geq 1.0 \mathrm{ng} / \mathrm{ml}$ for at least two consecutive samples. In ovulatory estrus, ovulation date was considered as the day of estrus if estrus was followed by an increase in progesterone concentration within at next 7 days. Estrus was considered to be false when cow exhibited estrous behaviour signs but progesterone concentration remained on its basal level $(<1.0$ $\mathrm{ng} / \mathrm{ml}$ ) throughout the next 7 days.

The cow was considered having long post-partum anestrous period when not increase in progesterone level and or no palpable ovarian structures were detected for more than 60 days post-partum. If this case continued throughout the studied period, the cows were considered to have a sustained anestrous. If a certain CL remained in one location for $\geq 4$ weeks, the cow was considered to have a persistent CL. When a fully developed large follicle remained persistent without rupture for 10 days or more, the cow was considered as having a cystic follicle. Cow was considered having irregular ovarian activity when the ovarian cycles were spelt with period of anestrous or cessation of ovulation after regression of $\mathrm{CL}$ at least for $\geq 3$ weeks.

\section{Statistical analysis}

Data were analyzed using one way analysis procedure of SAS liner program (1995), Model included one factor, incidence of conception. Duncan's new multiple range test (Duncan, 1959) was used for the multiple comparison of the means. Chi square was used to test the significance of the percentages

\section{RESULTS AND DISCUSSION}

The percentage of the conceived (G1) and non-conceived cows (G2) during the experimental period was $51.9 \%$ and $48.1 \%$, respectively ( Table 1 ). The depression of the number of conceived cows in this study may be attributed to limitation of the experimental period (120 days post-partum) and/or this study was carried out during the summer which characterized with low conception rate (Eicker et al., 1996).

\section{Post-partum anestrous period}

During the experimental period $90 \%$ of experimental cows had post - partum anestrous period ranging between 21 and 101 days with an average of $45.5 \pm 3.7$ 
days. Progesterone concentration throughout this period averaged $0.3 \pm 0.03 \mathrm{ng} / \mathrm{ml}$. Anestrous period was insignificantly shorter $(\mathrm{P}<0.05)$ in G1 than G2 (Table 1), while average of progesterone concentration throughout the anestrous period was similar (Table 1). The overall mean of post-partum anestrous period is in agreement with the averages previously reported on Friesian cows in Egypt (Kadoom, 1991 and Swiefy et al., 2001), the basal level of progesterone during post-partum anestrous period determined is in accordance with the previous report of Vetez and Randel (1993) and Swiefy (1997).

Table 1. The post-partum ovarian activity in conceived (G1) and non conceived (G2) Friesian Cows (mean \pm SE) during the first 120 days post-partum

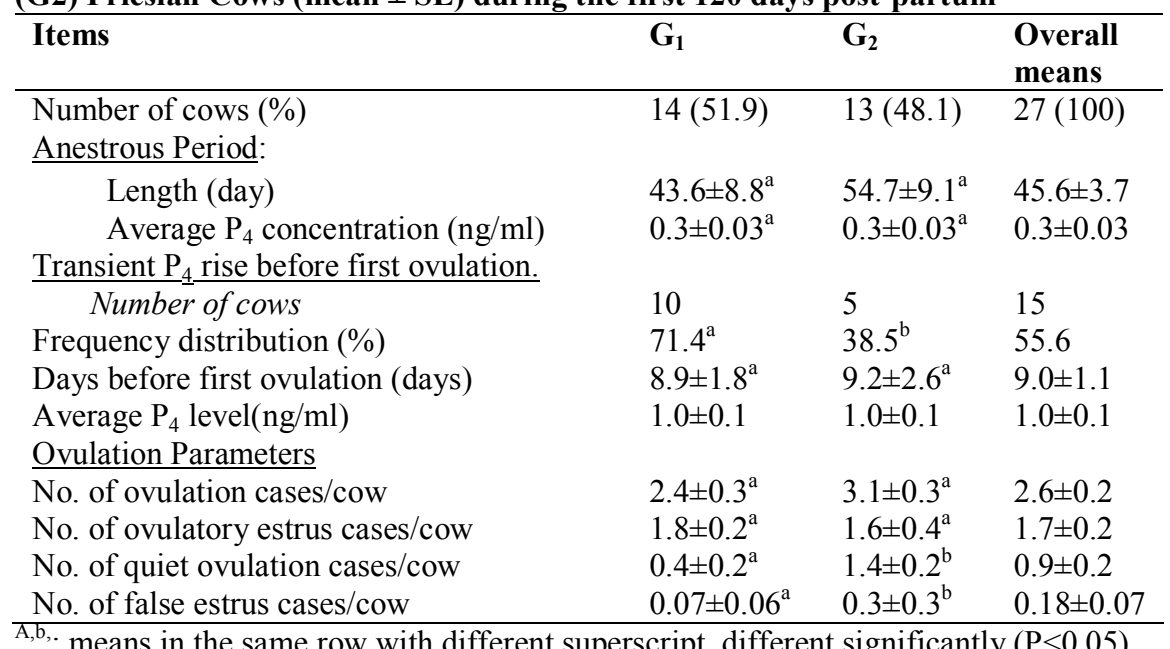

${ }^{\mathrm{A}, \mathrm{b}}$, : means in the same row with different superscript, different significantly $(\mathrm{P}<0.05)$

In 15 animals $(55.6 \%)$ a temporary elevations of progesterone was observed $9.0 \pm 1.1$ days before first ovulation with concentration of $1.0 \pm 0.1 \mathrm{ng} / \mathrm{ml}$. The transient rise in progesterone concentration before the first post-partum ovulation in the present study is similar to that reported by Vetez and Randel (1993), Weath et al. (1996) and Swiefy (1997). Occurrence of the transient progesterone rise before the first post - partum ovulation was observed in G1 with higher percentage than the other group (Table 1), while period between the transient progesterone rise and the post - partum first ovulation was almost similar in the two groups. Furthermore the same trend was observed in the average progesterone concentration $(1.0 \pm 0.1 \mathrm{ng} / \mathrm{ml}$ in each group)

In other three cows $(10 \%)$ the anestrous period extended for the whole experimental period. The incidence of sustained post - partum anestrous percentage throughout the course of the experimental period (120 days post-partum) is longer than that of Swiefy (1997) who stated that the values ranged from $3 \%$ to $5.3 \%$. This sustained anestrous could be attributed to the adverse effects of the environmental conditions on the hypothalams-hypophyseal-gonadal axis. 


\section{Ovarian activity:}

Although number of ovulations / cow was higher in G2, number of ovulatory estrus / cow was almost the same in the two groups. While average of quiet ovulation cases / cow, false estrus cases /cow and the number of ovarian cycles/cow were lower $(\mathrm{P}<0.05)$ in $\mathrm{G} 1$ than $\mathrm{G} 2$ (Table1).

\section{Ovarian dysfunction:}

Nine out of twenty seven cows had long anestrous period with an average of $68.5 \pm 5.1$ days. The percentage of cows which exhibited long anestrous cases was higher G2 than in G1. Quiet ovulation cases during the experimental period were higher in G2 than G1. G2 group had significantly greater percentage false estrus cases than it in G1 (Table 1). Quiet ovulation incidence at the first ovulation $(59.3 \%$, table 2) is in agreement with Donkin (1980) who reporting (about 64\%) while Shipka et al. (2000) reported higher percentage $(94.7 \%)$. The quiet ovulation cases may be attributed to the common practices of heat detection (two times daily ) which would lead to misdetection of many estrus cases particularly for those begun and terminated at night (Swiefy, 1997).

A single case of cystic follicle was observed in G1 while two cases were observed in the other group G2. Two cases of persisted corpus luteum and four cases of cessation of ovulation were detected only in non conceived group (Table 2).

Table 2. The frequency distribution (\%) of post-partum ovarian dysfunction types in conceived (G1) and non conceived (G2) Friesian Cows during the first 120 days post- partum

\begin{tabular}{lccc}
\hline Items & $\mathbf{G}_{\mathbf{1}}$ & $\mathbf{G}_{\mathbf{2}}$ & $\begin{array}{c}\text { Overall } \\
\mathbf{\%}\end{array}$ \\
\hline Long anestrous period & 21.4 & 46.1 & 33.3 \\
Quiet ovulation: & & & \\
At the first ovulation & 50 & 69.2 & 59.3 \\
At the experimental period & $18.2^{\mathrm{a}}$ & $49.2^{\mathrm{b}}$ & 33.3 \\
False estrus & $7.1^{\mathrm{a}}$ & $38.5^{\mathrm{b}}$ & 22.2 \\
Cystic follicles & 7.1 & 15.4 & 11.1 \\
Persistent CL & 0.0 & 15.4 & 7.4 \\
Cessation of the ovulation & $0.0^{\mathrm{a}}$ & $30.8^{\mathrm{b}}$ & 14.8 \\
A,b : means in the row with different superscript, different significantly $(\mathrm{P}<0.05)$
\end{tabular}

\section{Ovarian cycles:}

Only 21 out of 30 studied cows $(70 \%)$ had one or more complete ovarian cycle (average $2.2 \pm 0.3$ cycles /cow) during the experimental period. The overall means of ovarian cycle length was $21.1 \pm 0.8$ days. The equality of mean length of ovarian cycles in the two experimental groups (Table 3) was earlier reported by the Ghash et al.(1996) who found the mean length of ovarian cycle in repeat breeder and normal cows were 20.6 and 20.4 days, respectively.

The progesterone profile characteristics of the preconception ovarian cycle in $\mathrm{G} 1$ and the ovarian cycle throughout the experimental period in G2 shows that $81.8 \%$ and $57.1 \%$ of ovarian cycle in G1 and G2 respectively were normal ovarian cycles. The period lapsed for progesterone to reach a level of $1.0 \mathrm{ng} / \mathrm{ml}$ was little lower in G1 than G2. The maximum progesterone level was attained after $11.5 \pm 1.0$ and 12.5 
\pm 0.6 days of estrous cycle in G1 and G2, respectively, with significantly high maximum progesterone value in G1. Therefore, the area under the progesterone curve during complete cycles was significantly high in cycles before conception in $\mathrm{G} 1$ comparing with cycles during post partum period in G2 (Table3).

Table 3. Progesterone profile characteristics (MEAN \pm SE) of the pre-conceived ovarian cycle in conceived cows (G1) and the ovarian cycles during the first 120 days post-partum in non conceived cows (G2)

\begin{tabular}{|c|c|c|c|}
\hline Items & $\mathbf{G}_{1}$ & $\mathbf{G}_{\mathbf{2}}$ & Overall means \\
\hline Number of cycles & 11 & 28 & 39 \\
\hline Cycle length (days) & $20.7 \pm 1.6$ & $21.6 \pm 1.0$ & $21.4 \pm 0.8$ \\
\hline Number of cycle/cow & $1.6 \pm 0.3^{\mathrm{a}}$ & $2.8 \pm 0.3^{\mathrm{b}}$ & $2.7 \pm 0.3$ \\
\hline Length of ovarian cycle & $20.2 \pm 0.9^{\mathrm{a}}$ & $21.6 \pm 1.1^{\mathrm{a}}$ & $21.1 \pm 0.8$ \\
\hline Days to reach $\max P_{4}$ level & $11.5 \pm 1.0$ & $12.5 \pm 0.6$ & $12.2 \pm 0.5$ \\
\hline Max value of $P_{4}$ level $(\mathrm{ng} / \mathrm{ml})$ & $6.3 \pm 0.6^{\mathrm{a}}$ & $3.4 \pm 0.4^{\mathrm{b}}$ & $4.2 \pm 0.4$ \\
\hline $\begin{array}{l}\text { Area under } P_{4} \text { curve } \\
\left.\text { (arbitrary units of } \mathrm{cm}^{2}\right) \\
\text { Ovarian cycle types. }(\%) \text { percentage }\end{array}$ & $9.3 \pm 1.3^{\mathrm{a}}$ & $6.1 \pm 0.8^{\mathrm{b}}$ & $7.0 \pm 0.7$ \\
\hline Short cycle & $1(9.1)$ & $7(25)$ & $8 \quad(20.5)$ \\
\hline Normal cycle & $9(81.8)$ & $16(57.1)$ & $25(64.1)$ \\
\hline Long cycle & $1(9.1)$ & $5 \quad(17.9)$ & $6 \quad(15.4)$ \\
\hline
\end{tabular}

The physiological reason (s) of conception failure in studied non conceived cows is most probably due to : (i) the low percentage of cows which had transient progesterone rise before the first ovulation post - partum $(\mathrm{G} 2,38.5 \%)$ compared with conceived cows $(\mathrm{G} 1,71.4 \%$, table 1) may result in decrease of pregnancy maintenance because this progesterone rise may play an important role in the initiation of ovarian cycles (Peters and Lamming, 1984) and may have a role in preparation of the cow's reproductive tract for pregnancy (Weath et al., 1996). (ii) Reduction of progesterone profile characteristics of non conceived ovarian cycles than pre conception ovarian cycle in conceived cows (table 3) may effectively result in starvation of the conceptuses which may cause early embryonic mortality (Royal et al.2000), Therefore, the incidence of long ovarian cycle observed in non conceived cows was higher (table 3 ) which indicates that pregnancy may have been occurred but the embryo failed to survive during early stage of pregnancy (Peters, 1996). Furthermore, Kerbrot and Disenhous, (2000) reported that animals with a normal progesterone profile had a shorter interval to first insemination and higher conception rate than abnormal once . (iii) non-conceived cows (G2) compared with the conceived ones (G1) had significantly higher false estrus cases/ cow $(0.3 \pm 0.2$ vs. $0.07 \pm 0.06$, respectively) and quiet ovulation cases / cow ( $1.4 \pm 0.2$ vs. $0.4 \pm 0.2$, respectively), in the first case the cow was served without incidence of ovulation, while in the other case, the number of ovulation which not accompanied with insemination was higher. (iv) The incidence of short ovarian cycles in non-conceived cows (table 3 ) is considered as one of the major problems which leading to lowered fertility (Rekwot et al. 2000) furthermore, cessation of ovarian activity in non 
conceived cows (table 2) may cause the decrease of conception rate (Nakao et al. 1992).

The present findings indicate that animals with a normal ovarian activity had a shorter interval to first insemination and higher conception rat than abnormal one.

\section{REFERENCES}

Byongkyu, K., C. Hansum, G. Sang Gong, S. Changho, and K. Hyunku, 1994. Progesterone assays as an aid for improving reproductive efficiency in dairy cattle. 4- Milk progesterone profile for monitoring post-partum ovarian activity. Korean Journal of Veterinary Research, 34 (4):881.

Dawuda, P.M., L.O. Eduvie, K.A. Esievo and E.C. Molokwn, 1989. Silent estrus manifestation in Nigerian Bunaji-Zebu cow. Animal Reproduction Aci., 21:79.

Donkin, E.F., 1980. Reproductive activity of dairy cows post-partum. 3- Sequential relations between ovarian cycles. Zimbabwe J. Agricultural Research, 18(2):81.

Duncan, D.B., 1959. Multiple range and multiple "F" tests. Biometrics, 11:1.

Eicker, S.W., Y.T. Grohn and J.A. Hertl, 1996. The association between cumulative milk yield, days open and days to first breeding in New York Holstein cows. J. Dairy Sci., 79:235.

Ghash, S.K., S.R. Agarwal, U. Shankar and M.C. Yadav, 1996. Pattern of estrous cycle and its aberrations in repeat breeding crossbred cattle. Indian J. Anim. Reproduction, 17 (1) 27.

Kadoom, A.K.A. 1991. Hematological and biochemical studies in Friesian cows during calving-conception interval. M. Sc. Thesis, Alexandria Univ. Egypt.

Kamimura, S., H. Sameshima, A. Enomoto and K. Hamana, 1994. Turnover of ovulatory and non-ovulatory dominant follicles in post-partum Japanese Black cows. J. Reproduction and Development, 40(3):171.

Keeling, B., R. Rajamahendran and V. Ravindran, 1992. Detection of post-partum ovarian activity in cows using on - farm progesterone ELISAs. VeterinaryRecord., 131:291.

Kerbrot, S. and Disenhaus, G. (2000). Profiles of luteal activity and performances of reproduction between calving and first service. Animal Breeding Abstracts, 69(6):540.

Nakao, T., H.M. Mariyos and K. Kawata, 1992. The effect of post-partum ovarian dysfunction and endometritis on subsequent reproductive performance in high and medium producing dairy cows. Theriogenology., 37(2):341.

Opsomer, G., M. Coryn, H. Deluyker, A. de. Kruif and A. De-Kruif, 1998. An analysis of ovarian dysfunction in high yielding dairy cows after calving based on progesterone profiles. Reproduction in Domestic Animals, 33:3-4, 193.

Peters, A.R. and Lamming, GG.E. (1984). Reproductive activity of the cow in the post-partum period. II. Endocrine patterns and induction of ovulation. British Veterinary J., 140:269.

Peters, A.R., 1996. Embryo mortality in the cow. Animal Breeding Abstracts, 64(8):587.

Rekwot, P.I, D. Ogwu, V.O. Sekoni and E.O. Oyedipe, 2000. Serum progesterone profiles of Zebu cattle (Boss indicus) in relationship to conception and repeat breeding after artificial insemination. Anim. Reproduction Sci, 63:41. 
Royal, M.D., G.E. Mann, and A.P.F. Flint, 2000. Strategies for reversing the trend towards sub fertility in dairy cattle. Vet. J., 160:53.

SAS, 1995. SAS user guide statistics version Sedition SAS Inst. Cary, NC, USA.

Schopper D., R. Schemer and R. Claus, 1989. Analysis of post-partum fertility in dairy cows under practical farm conditions by means of milk progesterone profile. Zuchthygiene, 24(2):67.

Shipka, M.P., 2000. A note silent ovulation identified by using radio telemetry for estrous detection. Applied Animal Behaviour Sci., 66:153.

Stagnaro, G.C., C.J. Liaque, N. Madridbury, D. Medina and J. Morabes, 1994. Progesterone profiles in repeat-breeding cross bred cows. Anim. Breeding Abstracts, 641(3):217.

Swiefy, S.A., 1997. Post-partum reproductive performance of Friesian cows in relation to season of calving and level of milk production. Ph.D. Thesis, Fac. Agric., Cairo Univ., Egypt.

Swiefy, S.A., A.M. El-Gaafarawy, E.A. Omar, F.M, Fouad and A. Sohair, A. Fawzy. 2001. Using prostaglandin-F analogue to improve the post calving reproductive performance in Friesian cows. Minufia, J. Agric. Res., 26 (5):1221.

Vetez, J.S. and R.D. Randel, 1993. Relationships between plasma progesterone and 13-14 Dihydro-15-Keto-Prostaglandin F2 $\alpha$ and resumption of ovarian activity during the post-partum period in Brahman cows. Theriogenology, 39:1377.

Weath, L.A., J.C. Whittier, S.M. Azzam, G.H. Deutscher and J.E. Kinder, 1996. Relationship between circulation progesterone and conception at the first postpartum estrus in young primiparous beef cows. J. Anim. Sci., 74:616.

Zduczyk, S., A. Zebracki, T. Glazer, T. Janowski and A. Ras, 1992. Investigations of the occurrence and treatment of ovarian function in cows under large farms conditions. Acta-Academia Agriculture-ac-Technica-Olstenensis-Veterinaria, No. 20,87 . 


\section{النشاط المبيضى بعد الولادة فى أبقار الفريزيان فى فصل الصيف فى مصر}

سويفى عبد الرحيم سويفى'، صالح عبد الحميد إبراهيم'، ايمن مصطفى سعيد'، سـالم محمد

1 - معهد بحوث الإتتاج الحيوانس، ونلاة النراعة، جيزة، مصر، r - قسم الإنتاج الحيوانس، كلية

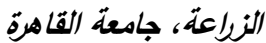

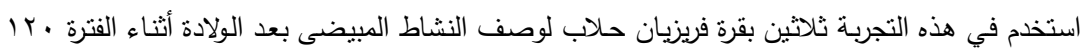

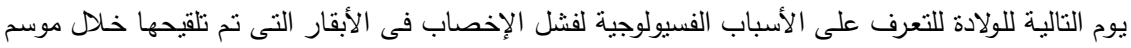
الصيف فى مصر

تم التعرف على النثاط المبيضى من خلال إجراء الجس المستقيمى وقياس تركيز هرمون البروجيستيرون بالدم مرتين أسبوعيا

تم قياس الفترة بين الولادة واول تبويض وكذللك تم قياس طول الدورة المبيضية الواحدة والنشاط المبيضى بها

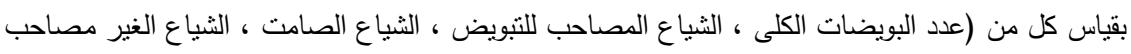

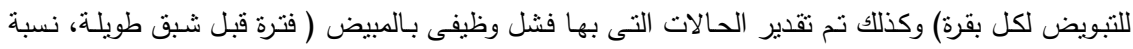

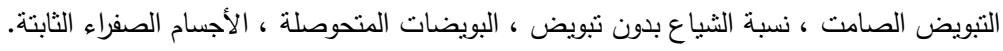

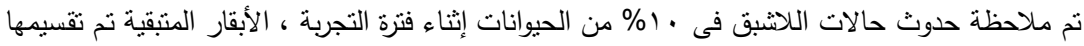

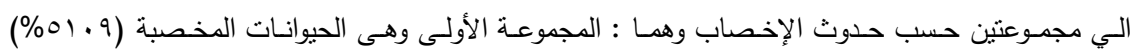

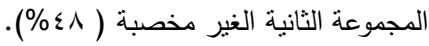

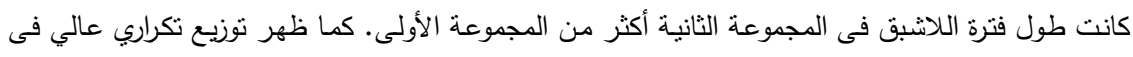

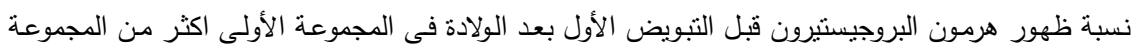

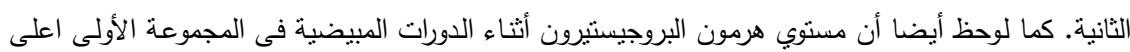

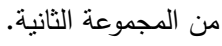

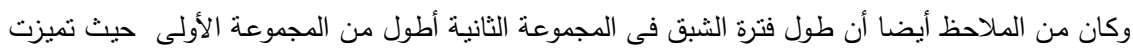

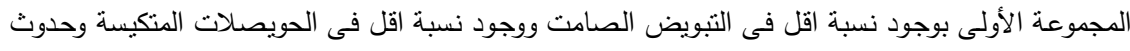

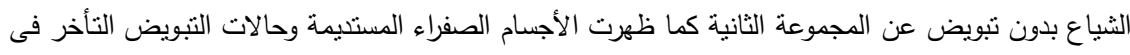

